DOI https://doi.org/10.36059/978-966-397-195-7/2-21

\title{
SOCIOLOGICAL AND LEGAL PROBLEMS OF FORMATION OF ECOLOGICAL STATE
}

\section{Kostytsky V.}

\section{INTRODUCTION}

The modern American and European state, which in Ukraine was fairly called "civilized", is essentially a liberal state, including Ukraine, which was incorporated into the essence of the state and the model of government by the parents of the Constitution of Ukraine in 1996, including the author of this article ${ }^{1}$. So far as, the content of the liberal model of the state, which is put into the Constitution of Ukraine as well, involves a number of important factors, in particular, the rule of law, the primacy of human rights and freedoms, proclaimed the highest social value. Here we also have the restriction of the state by law: the content and direction of the state's activity determine the human rights and freedoms (Article 3 of the Constitution of Ukraine), bodies of state power and bodies of local self-government, their officials are obliged to act only on the basis, within the limits of authority and in a way, stipulated by the Constitution and laws (Article 19 of the Constitution of Ukraine).

As a theoretical and methodological substantiation of what model of the state to replace the post-industrial state in the new world order, the advisability of combining the strengthening of state functions and the need to preserve liberal human rights and freedoms against the background of global environmental challenges, creation of an ecological state.

\section{Problems of the modern state: liberalism and the organization of state power}

Today, the modern state of European-American civilization faces challenges that are almost unrealistic to realize within the traditional framework of a liberal state. It is an issue of environmental protection, ensuring human rights in a favorable environment and avoiding a global

${ }^{1}$ Kostysky V.V. Ecology of Transition: Law, State, Economy (Economic and Legal Mechanism of Environmental Protection in Ukraine) / V.V. Kostysky; Institute for Legislative Predictions and Legal Expertise. - K.: USSB SME Eusmeu, (Series "Ecological Library"; № 5) (Library of the magazine "Small and Medium Business. - 2003. - 772 p. 
ecological disaster, combating poverty, combating terrorism, harmonizing the interests of the state and society, and the interests of the participants in mass transfers to the European Union from the countries of North Africa and the Middle East. For Ukraine, the question of choosing the optimal model of the state is complicated by the problems of the transition period, including external aggression and the loss of control over the part of the sovereign territory, the need for the reform of the administrative and territorial system in order to eliminate the remnants of the administrativecommand system, raw material orientation of the economy, prosperity of corruption, imbalance between the branches of power and frequent political crises, incompleteness of the structuring of civil society and party building, and others.

Therefore, the following question emerges: what model of the state should replace the legal state without losing its value gains, such as the rule of law, the distribution of power, the guarantee of human and civil rights and freedoms. The answer to this question is the theoretical and methodological justification of certain changes in the Constitution of Ukraine, which is today the Social Contract between the Ukrainian people on human and civil rights and freedoms and on the model of state power, as well as an agreement between civil society and the state on mutual rights and obligations, on which the state becomes a service of the people, and the understanding of the essence, tasks and functions of the state, which should combine liberal values with the strengthening of state interference in the sphere of public life associated with the safety of society and human.

The decision of this issue should take place with the contition of solving a number of tasks, the first of which we can call the necessity to organize social life on the basis of public-state partnership, built on legal principles.

Law as a social phenomenon is a product created by a society ${ }^{2}$ on the basis of moral laws established by the Almighty, the Supreme Mind. The multitude of law is that this social phenomenon is a bank of human and civil rights and freedoms, a treasury of social values, but it is also the value itself, the property of the spiritual culture of society. Law is expedient, as a system of rules and regulations law is the most perfect regulator of social relations. Finally, law is a means of consolidation and

${ }^{2}$ Kostytsky VV Ecological law as a theological and sociological phenomenon / V. Kostytsky // Ecological law of Ukraine. - 2013. - № 1. - P. 4-12. 
an instrument for the organization and functioning of power, as the institutional capacity of the subject of law and subject of public relations to make their orders obligatory for others.

In the system of power we distinguish the spiritual power, which is based on the Highest Will, the Moral Imperative, which are "placed" in faith and supported by religion. The next levels of government are the power of the people, which is realized by them through the state (state power) and local self-government, the power of capital and the "fourth" power - the power of mass media. The second task consideration of this issue must be deprived from myths and cliches.

Today there are grounds to say that the idea of building the legal state is based on the principle of separation the power, has become an integral part of the national idea in Ukraine through the implementation of its European aspirations, providing "growing" in European and world community, with the help of criterion to treat Ukraine to the list of civilized nations, part of the mentality and outlook of the modern Ukrainian person.

Today, with the expiry of the twenty-two years, the author of these lines, both co-author of the Constitution of Ukraine, resolved on June 28, 1996, has to admit that at that time a methodological mistake was made, which is now the cause of political confrontations and failures in the work of the state apparatus. It is a question of the fact that the principle of modeling of state power in the draft Constitution of Ukraine was based on the principle formulated by John Locke and Charles Montesquieu 280 years ago regarding the division of power into the legislative, executive and judicial, the principle, which now does not cover all functional branches of the state machinery.

At the same time, we as co-authors of the Constitution of Ukraine, did not take into account the following points:

- since the scientific concept of D. Locke and S. Montesquieu, there has been considerable time, when the state apparatus has been significantly improved and complicated;

- in the $17^{\text {th }}-18^{\text {th }}$ centuries, the idea of the division of power was based on the task of not only not so much national sovereignty, but the task of limiting absolute royal power and depriving society of possible monarchy's arbitrariness if he could not or did not want to be wise;

- when preparing the draft of Constitution of Ukraine, its developers did not have enough time to work out the model of local self-government, 
which under the same constitutional requirements is already the authority of the territorial community, has declared property and budget autonomy;

- the level of legitimacy of the President of Ukraine elected by people is the same as that one of the entire Verkhovna Rada, but under his authority the President cannot be assigned to any of the indicated branches of power.

Therefore, when we use the famous Montesquieu formula of dividing power into legislative, executive and judicial, and the media is called the fourth authority, we make several mistakes at once: the media can not be in this list, because it is not a state power. In addition, state power is limited by law. In Ukraine, this is article 3 of the Constitution, which provides that the content and direction of the state determined by human rights and freedoms, the approval of which is the main responsibility of the state, and the state is responsible for his activities to human. Here we also should mention Article 19, according to which the bodies of state power and local self-government, their officials are obliged to act only on the basis, within the limits of authority and in the manner envisaged by the Constitution.

The third task of modeling the modern state is the return of power to the people and the exercise of state and self-government power in the interests of the people. In the end, according to Article 5 of the Constitution of Ukraine, people are the bearer of sovereignty and the only source of power. The power of the people ${ }^{3}$ is exercised by them through the channels of direct democracy (elections, referendum, the right of legislative initiative), as well as by the state through the legislative, judicial, control and oversight, attestation and executive branches of government. Local self-government implements the power of the people through local referendums, territorial councils, their executive bodies and the institution of village, settlement and city mayors, as well as through public self-government bodies - home, street, quarterly committees, parental committees in schools, community councils.

Of course, now we are talking about the power of the people and state and self-governmental power. Other forms of government should be considered in a wider statement only in connection with the legal

\footnotetext{
${ }^{3}$ Kostytsky V.V. Power of the people: seven functional branches of power (Renaissance problems in the theory of law). - Small and Medium Business, 2010. - P. 4-14; the same one: Distribution of power in legal state and social and normative fixing of the idea of freedom and democracy. - Sociology of law. - 2011, № 2. - P. 3-6.
} 
problems that arise in the process of exercising power: the question of the relationship between church and state, registration of religious organizations, church property, capital power is the subject of study in connection with the legal issues of the activities of transnational corporations, guarantees of entrepreneurship, legal issues of the activities of banks and other financial institutions. It should be noted that capital power is often "imperceptible" to law, since it is implemented beyond the law as well: influence on elections, support of political parties, lobbying, influence on higher state power, etc.

The fourth task is to ensure the optimality of power. The balance of rights and the balance between civil society sectors and between civil society and the state is optimal for a person and a normal social life. Such an ideal state, in our opinion, is achieved with the advent of an era of a law-governed state, which manifests itself as a kind of only possible compromise between the etatist state of the past, which exaggerated the society and controlled it up to the interference with private and family life, as well as extreme liberalism, accompanied by manifestations of anarchism, the war in the sectors of the economy, the ohlocratic methods of exercising power and even the abuse of law.

We regard the creation of an optimal model of the institution of power as one of the most important constituents of the Constitution of Ukraine the Social Contract, along with the consolidation of human rights and freedoms and the definition of guarantees for their implementation.

The greatest prosperity the idea of legal state ${ }^{4}$, before they became the property of political and legal practice, acquired in the period of the birth of early capitalist forms of organization of social life. These ideas were reflected in the writings of the Enlightenment authors and representatives of the German classical philosophy,and these ideas were associated with the need to overcome monarchical absolutism, and then, in particular, in France and the United States, there are ideas of limiting power by law, the abandonment of the monarchy and the transition to a republican form of government.

So, according to Russo's imagination, state is governed by a social contract, which serves as the basis of all rights, and its purpose is to establish a common $\operatorname{good}^{5}$. In his writings, we see the prospects for the

\footnotetext{
${ }^{4}$ Kostytsky V.V. The distribution of power in legal state and the social and normative fixing of the idea of freedom and democracy. - Sociology of law. - K., 2011, No. 2. P. 3-6.

${ }^{5}$ History of political and legal studies: Reader for law schools and faculties / Comp. and total ed. Prof. Dr. Dr. East. Sciences G.G. Demidenko. - X : Fact, 1999. - C. 223.
} 
establishment of national sovereignty, the expansion of mechanisms for the exercise of the people's sovereignty, the guarantee of civil liberties, the concept of universal will as the basis for legislative activity, etc ${ }^{6}$.

Close to such an understanding of a state that does not interfere in the life of civil society and has a minimal impact on its other non-state sectors, were the views of I. Kant, which is fairly considered the founder of the doctrine of legal state ${ }^{7}$.

\section{Ecological function as an integral feature of the modern state}

Civil society, as a result of European-American development, is based on pluralism, which is based on the principle of self-determination of the individual, guaranteeing the human and civil rights and freedoms, statepublic partnership.

The existence of ecological law $^{8}$ system and social necessity in the environmental protection require the ecological state function separation.

In legal literature the state functions are the basic directions of its activity directed on solution of the common matters of subjects of society. At the same time realization of some state functions is executed through the activity inside and outside of the country by participating in the international community life. The ecological function requires its separate consideration in the system of functions of state as a political organization of society.

State ecological function came into being not long ago and simultaneously with intensifying of the problem of natural environmental protection. Earlier the question of regulation of nature using and protection was included in the state economic activity and considered as manifestation of its economic function ${ }^{9}$. Worsening of ecological situation, increasing of the role and importance of interaction between society and nature resulted into the necessity of appearance of separate ecological function among other internal state functions.

\footnotetext{
${ }^{6}$ The history of political and legal doctrines of the XVII - XVIII centuries. / Editorial.: Gratsiansky P.S. and others - M.: Science, 1989. - S. 116-129.

${ }^{7}$ The history of political and legal doctrines of the XVII - XVIII centuries. / Editorial.: Gratsiansky P.S. and others - M.: Science, 1989. - P. 198; Sokolov A. Kant and Contemporaneity (concept of legal state in the mirror of comparative law) // Political Reading. - 1995. - № 1. - P. 4; Timoshenko V.I. Legal power: theoretical-historical researches. - K : Naukova Dumka, 1994. - P. 16.

${ }^{8}$ Kostytsky V.V. Environmental Law of Ukraine: [textbook] 1 book. / V. Kostytsky, Drohobych: Circle, 2012. -360 p.

${ }^{9}$ Kostytsky V. Ecological function of the state and economic and legal mechanism of environmental protection // Law of Ukraine. - 2004. - № 1. - P. 147.
} 
At the same time there are other grounds of separation of ecological function from the modern state functions in special scientific literature. Sometimes such grounds are predefined by the environmental protection requirements and quality new social and economic situation, i.e. transition of the world vanguard to the stage of post-industrial or information development with the following processes: increase of demand on the corresponding scientific and information resources, displacement of accents in the means of using of natural resources; transition to the economy of preservation of resources; transfer of all social life to the socalled stable development.

In professor V. Petrov's opinion, the main content of the state ecological function is determined by the following measures:

- detection and evaluation of the natural resources condition and natural environmental protection;

- ecological planning, financing, logistical support;

- drafting of legal norms and realization of control over their compliance;

- establishment of the governmental machinery in the sphere of nature protection and sustainable use of natural resources;

- organizing of ecological monitoring, state control over natural environment condition;

- drafting of the norms and standards concerning natural environment quality;

- organizing and execution of ecological examination of projects, equipment and other measures which influence on the natural environment;

- organizing of research activity on the problems of ecology;

- ecological education, selection and training of personnel;

- organizing of international cooperation in the sphere of natural environmental protection ${ }^{10}$.

It is a short list of those constituent elements which distinguish the state ecological function as its independent and important function.

State ecological function is realized by the appropriate economic, organizational and legal mechanisms. In addition state legal mechanism is the instrument of implementation of ecological legal function as a new and

${ }^{10}$ Petrov V.V. The concept of interaction between society and nature - the scientific basis of environmental law / Methodological problems of law / Ed. M.N. Marchenko. - M : Moscow State University Publishing House, 1994. - P. 138. 
earlier unknown legal function. It is realized side by side with traditional legal functions, such as: political, economic, cultural and educative, etc. Formation and development of legal ecological function is the result of development and deepening of social contradictions between society and nature, understanding of the need and necessity of considerable extension of legal intervention in the regulation of relations in the sphere of environmental protection and using of natural resources.

The purpose of legal ecological function is ensuring of natural environment quality under the conditions of social economic development by legal regulation instruments. This purpose is attained by drafting, adoption and application of legal norms represented the requirements of ecological regularities concerning interaction of society and nature which consolidate the scientifically proved norms of economic influence on the environment ${ }^{11}$.

It is interesting that in one of the latest theoretical legal research concerning analysis of the state functions professor A. Pigolkin included the legal function (or function of freedom and ownership ensuring) and function of communication system formation in the state functions ${ }^{12}$.

In our opinion, the analysis of correlation between all state functions is more efficient and depends on their objects.

Certainly, the ecological function is not permanent concomitant of state organization of society. Moreover, it is possible to ascertain its late appearance as a separate state function only in the second part of the XX century. Till that time this function was fundamental part of state economic function and it was realized as a constituent part of state economic policy. However, today in some special scientific research we can find the environmental protection interpretation as a component part of state social and economic policy ${ }^{13}$.

State ecological function began to separate only for some time past due to the progressing worsening of the natural environment condition of the planet. The modern manufacture development (output of minerals, development of the chemistry, metallurgy, etc.), using of the newest

${ }^{11}$ Petrov V.V. The concept of interaction between society and nature - the scientific basis of environmental law / Methodological problems of law / Ed. M.N. Marchenko. - M : Moscow State University Publishing House, 1994. - P. 138.

${ }^{12}$ Problems of the general theory of law and state. Textbook for universities / Under commonly. ed. V.S. Nersesyan. - M : "Norma", 2001.

${ }^{13}$ Combating environmental crimes. (Criminal and Criminal Investigation). - K : Sciences. opinion, 1994. - P. 9. 
technologies by which human breaks the natural balance that existed during millions of years, appearance of huge amount of wastes including the atomic manufacture wastes do harm the ecosystem and have irreversible consequences. For example, the Chornobyl nuclear disaster in Ukraine was constitutionally recognized as a planetary catastrophe. Therefore, a state more and more actively operates in the sphere of recovery of the broken balance.

This function objectively became general function for all countries. Nowadays many international agreements on the defence of environment (flora, atmospheric air, etc.) were concluded ${ }^{14}$.

So, we can consider the state ecological function both as internal and external. This statement is absolutely fair because of the following reasons:

- intensification of the processes of globalization of ecological problems (sometimes scientists even stress on the fact that humanity has already gone across a limit which detach out planet from ecocatastrophe and now all states have to coordinate their efforts for its warding off);

- unification of values of the modern states with globalization processes which also cover social and political and legal spheres of social life (harmonization of legislation; formation of democratic legal social states; recognizing of legal rule, priority of human rights, democratic development principles, etc. as the indispensable state attributes).

Today we can see a raise of the role and importance of this state function on the example of constitutions adopted in the second part of the $\mathrm{XX}$ century. As a rule, they consolidated the state policy novels in the sphere of environmental protection and defence. Constitutional consolidation of the state ecological function is the first evidence of importance of this state activity direction under the present-day conditions.

During the Soviet times scientists began to distinguish state ecological function. At first it was made by O. Kolbasov and Y. Shemshuchenko ${ }^{15}$. Now it is especially topical function taking into consideration a globalization of ecological problems and only societies which are wellorganized and well-coordinated by the state and which defend the common civilization values.

\footnotetext{
${ }^{14}$ Chirkin V.E. The modern state. - M : International. Relations, 2001. - P. 203.

${ }^{15}$ Kolbasov O.S. Ecology: politics - law. - M : Science, 1976; Shemshuchenko Y.S. Organizational and Legal Issues of Environmental Protection in the USSR. - K : Sciences. opinion. $-1976-276 \mathrm{p}$.
} 
The second argument which confirms a need of the state intervention in the ecology defence process is the branched special legislation as the instrument of solving of ecological problems. At the same time such special legislation should consolidate a system of ecological rights and freedoms of human and citizen as one of the most important constitutional rights and freedoms.

Allocation of considerable budgetary funds for the environmental protection measures is another confirmation of realization of ecological function by the modern state. Specific of the state ecological function realization depends on the conditions of operating of different types and kings of states, their social and economic structure, special features of state national and political regime, civilization development condition.

\section{Ecological function and environmental policy of the state}

State ecological function can be realized only under the conditions of the modern democratic legal social state which has a complex of obligations to society and human, protects ecological rights and freedoms, takes care of the environmental protection by using of special instruments ${ }^{16}$.

The main positions regarding the essence and direction of the state ecological policy of Ukraine are included in the base legislative act on the questions of environmental protection, i.e. in the Law of Ukraine "On protection of the natural environment" dated June, $25^{\text {th }} 1991$. This law stipulates that Ukraine realizes the ecological policy on its territory, directed to the prevention of environment which is safe for life of animate and inorganic natures, defence of human life and health from negative influence of the natural environment pollution, achievement of the harmonious interaction between society and nature, protection, sustainable use and recreation of natural resources.

So, the ecological policy is one of the state activity directions which has corresponding priorities and tasks of social and economic, natural and social character.

We can separate two basic forms of state ecological policy realization, in particular: the ecological policy strategy and ecological policy tactics.

The ecological policy strategy is the course of state ecological policy, aimed at the long-term prospects and solution of the important economic and social tasks, tasks of cultural development, ensuring of state

${ }^{16}$ Muhamet - Irekle A. On the Function of the Rule of Law in Modern Nature Management. Monograph. - M : "NIA-Nature", 2002. - 272 p. 
ecological safety, preservation and increase of its natural potential and national wealth, defence of ecological rights and freedoms of physical and legal entities, increase of national well-being.

Ecological policy strategy (or ecological strategy) includes search of the national economy priority purposes, instruments and methods of their realization on the basis of purport of objective processes and tendencies of the environment condition, changes in environment and peculiarities of its protection which take place in the national and world economy, and taking into account the legal interests of ecological law subjects ${ }^{17}$.

Ecological tactics is a combination of the nearest purposes, tasks, instruments and methods of their achievement for realization of ecological policy strategy under the concrete conditions of the present development.

As a rule, the ecological strategy and ecological tactics measures are realized in legal forms. In particular, ecological policy legal consolidation is realized by the following instruments: determination of principles of domestic and external policy; prognoses and programs of economic and social development of Ukraine and its separate regions; programs of activity of the Cabinet of Ministers of Ukraine; purpose-oriented programmes of economic, scientific and technical and social development and corresponding legislative acts.

In general policy is a special activity on the administration of state and society, organizing and supervisory sphere of society which manage the economic, legal, social, cultural, and religious spheres, etc ${ }^{18}$. The term "policy" comes from Greece and means something state-related. This term takes rise from Aristotle's treatise "Policy" about state, administration and government.

From Aristotle's times and to the end of XIX century policy was considered as a doctrine about state, i.e. state level power. Nowadays there are several fundamental explanations of the term "policy", such as:

1. It is the relations between classes (as relations of consent, enslavement, supremacy, conflict and fight), groups, people (as domestic policy) and states (as external policy).

${ }^{17}$ Tomenko M. The Ukrainian Perspective: Historical and Political Foundations of Modern State Strategy / Political Studies. Issue 2. - K : Ukrainian Perspective Foundation, 1995 - P. 4; Development strategies of Ukraine: challenges of time and choice / E. Bazovkin, A. Belouk, O. Valevsky, et al. - K : NISD, 1994. - 177 p ; Valevsky O.L. State policy in Ukraine: methodology of analysis, strategy, mechanisms of implementation. - K : NISD, 2001. - P. 121-126.

${ }^{18}$ Politology. Textbook / Edited by prof. Kremena V.G., prof. Gorpacha MI - Kharkiv: Unicorn Printing Center, 2001. - 640 p. 
2. It is the supremacy, power and activity that attach the seizure of power and its using.

3. It is practical administration, normalization of social life (from Platon's times it was called as functional approach).

The policy can exist as the following kinds of activity:

- theoretical, intellectual activity which forms the political essence, mode of thinking and mentality;

- practical activity as organizing and control activity, arrival at a decision by the leaders, work with people, exchange of information, government authority operating, etc.

The policy is materialized by the government authority in the legal acts.

Ecological policy as a constituent of policy is a system of measures, aimed at ensuring of the natural environment quality, recreation of natural resources and creation of the proper ecological conditions of human life and practice of realization of these measures.

Ecological policy is a combination of methods and means of influence of state and other political institutes on the "society and nature" system with a purpose to solve its conflicts timely and ensure the favourable environment of existence of human and society at present and in prospect.

Separate scientists determine the ecological policy as an organizing and regulative and control activity of society and state directed to the environmental protection and improvement, ensuring of the normal vital activity and ecological safety of citizens. But this term reflects rather desirable than real things.

Ecological policy as ecological strategy and ecological tactics is a form of realization of the state ecological function. Ecological policy is the expression of forms and methods of realization of state ecological function in the concrete historical conditions by the concrete political systems. Therefore, analysis of ecological platforms of separate political forces and political parties, especially during pre-election company, is very important for evaluation of the ecological policy efficiency. In Ukraine the political parties continue to establish their own ecological priorities which do not have any real character ${ }^{19}$.

Subjects of the ecological policy realization are state, political parties, public organizations as subjects of civil society. State ecological policy

${ }^{19}$ Kostytsky V.V. Political Parties in the System "Civil Society and State" // Law of Ukraine.- 1995. - № 12; Kostytsky Vasyl. State-building processes are components of multiparty development in Ukraine (political and legal analysis). - K., 2002. -60 p. 
will be realized through the state ecological function as a direction of its activity. Some scientists attribute the state ecological function to its internal functions ${ }^{20}$. As state ecological function is the expression, direction of realization of state ecological policy which includes an internal and external policy it is logically to admit that state ecological function is the complex function and it is displayed as external and internal functions of ecological state ${ }^{21}$.

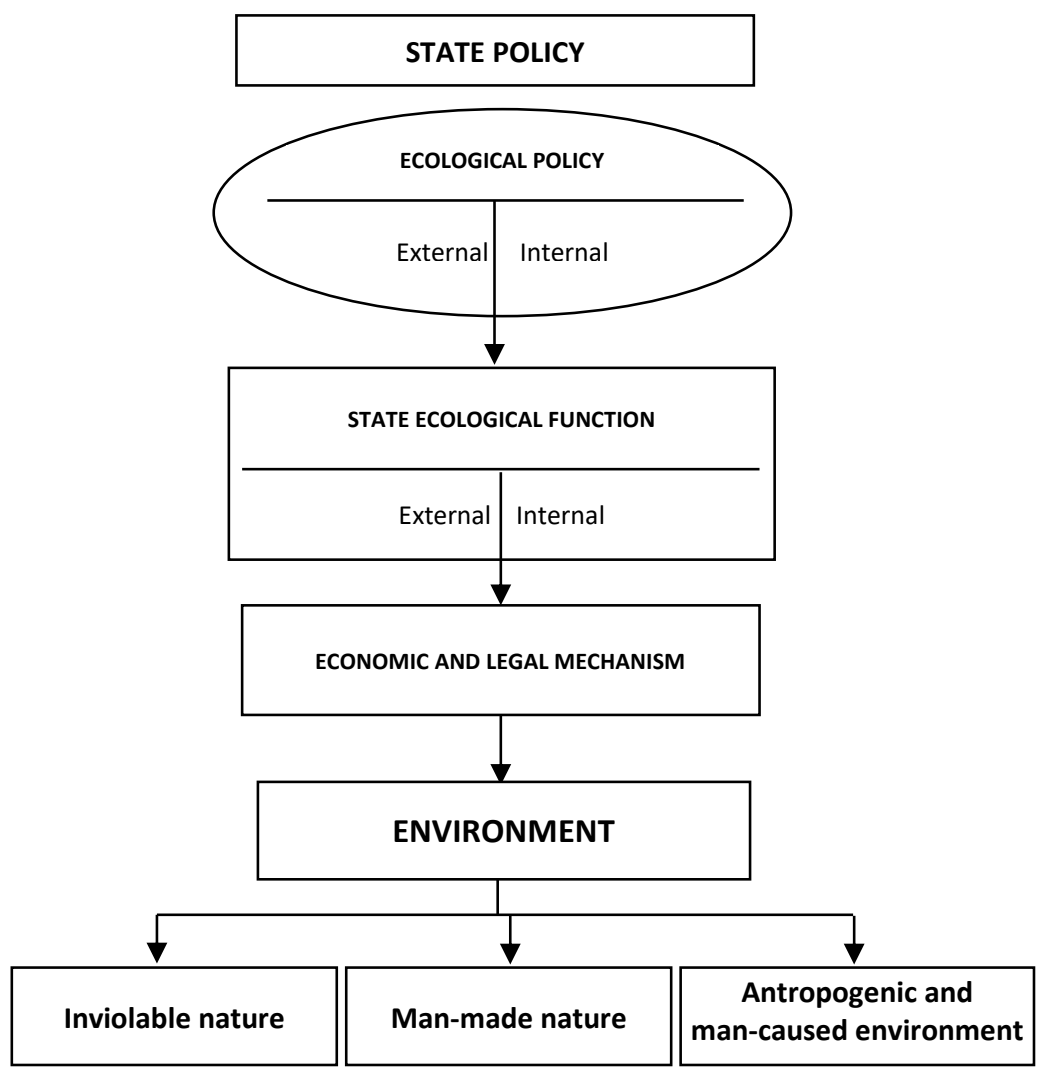

Fig. Mechanism of the state ecological policy realization

${ }^{20}$ General theory of state and law. Academic course in 2 volumes. Volume 1 . Theory of the State / Ed. M.N. Marchenko. - M : "Mirror", 1998. - P. 203-204.

${ }^{21}$ Kostytsky V.V. The modern state is an ecological state: a sociological-legal approach / V.V. Kostytsky // Sociology of Law. - 2018. - № 1-2 (24-25). - P. 102-110. 
State applies various instruments and mechanisms of regulation of economic activity in the sphere of management of nature or realization of ecological policy, purpose-oriented ecological programs and related with them programs of economic and social development. The main means of state regulative influence on the activity of market participants in the field of environmental protection are the following: ecological taxation; licensing; certification and standardization; application of standards and limits; regulation of prices and tariffs; granting of investment, taxation and other privileges; granting of dotations, compensations, purpose-oriented innovations and subsidies.

Terms, volumes, spheres and procedure of application of separate types of instruments of state regulation of economic activity are determined by the legislative acts and programs of economic and social development. Granting and suspension of privileges and advantages in the economic activity of separate categories of market participants are realized according to the laws.

\section{From ecological function to creation of ecological state}

Nowadays realization of the state ecological function foresees solving of strategic and tactical tasks. Strategic tasks of the state ecological strategic policy are considered in the following: preservation and recovery of natural biosphere ecosystems in the necessary extent; ensuring of stable development and environment which is suitable for human vital activity under the condition of the minimized risk of initiation of ecological emergencies.

Obviously, under the conditions of worsening of ecological problem Ukraine has to determine its new state role in this process.

Taking into account the experience of times of independence, we can make a conclusion about necessity in more absolutely and more effective using of the state-legal and organizing and administrative mechanics of the environmental protection ensuring. So, they should newly treat thesis that development of society and all its institutes including state and law is the natural and historic process developed according to the definite objective rules. Of course, in such approach the purposeful formation of state and legal systems according to the preconceived plan seems to be utopian $^{22}$. However, just transfer to the phase of stable civilization development as a quite new form of interaction between society and

\footnotetext{
${ }^{22}$ Spiridonov L.I. State and Law Theory. - M., 1996.
} 
nature and environmental protection foresees the systematic evolutional change of the state and legal mechanism.

In this context the American discoverer T. Hoja's research is quite interesting. He analyzed the methods of market economy in the American and Russian ecological laws and made a conclusion that "among all Western industrially developed countries the USA ecological law is mostly based on the administrative-command methods"23.

After proclaiming of independence of Ukraine Ukrainian scientists, politicians, officials focused their attention on the establishment of economic administration methods in the sphere of environmental protection and using of natural resources taking into account the negative experience of solving of ecological problems in the former Soviet Union.

The effective economical and legal mechanism of the environmental protection based on the interaction of administrative and economic instruments of solving of ecological problems and ensuring of stable development should be in the base of ecological strategy realization under nowadays transitional period conditions.

Modern phase and peculiarities of realization of the state ecological function are characterized by two opposite processes, such as: on the one hand, it is intensification and deepening of globalization processes; on another hand, there are certain tendencies of solving of national ecological problems on account of other states. But domination of the second tendency contravenes the possibility of averting of global ecocatastrophe and ensuring of the effective cooperation in the sphere of state ecological policy.

Ukrainian state needs the long-term transitional period for full value realization of its ecological function. Also the content of this period has no obligatory lie down in the deep social transformations which, obviously, are not entirely predetermined and guaranteed by the internal factors. Thus, in O. Dergachov's opinion, this period can not be a classic period of the "internal concentration", because the ecological function realization is fully impossible under isolation conditions in the modern globalized world. Today the open question on interaction between national and international ones arose in Ukraine in the context of polity strengthening, disclosure of prospects and improvement of the long-term strategy. This

${ }^{23}$ Hoya T. Methods of market economy in American and Russian environmental law // Bulletin of the International University. - The Law Series. - Issue 5. - M., 2001. - P. 152. 
problem becomes more complicated due to the historical lagging of the internal processes from prevalent international tendencies ${ }^{24}$.

The lagging of Ukraine from the progressive Western states in social and economic and political development circumscribes real limits in the state ecological policy realization. As a rule, Ukraine has unequal relations with more powerful partners that treat it only as a potential source of creation of the additional ecological dangers or so-called perspective "disposal tip of Europe".

The international context predetermines the substantial lagging or even falling out of Ukraine from general logic of civilization development and threatens with increase of the relative isolation, final removing to the periphery of such system of international relations which has the paradigm of stable development as its foundation. So, the state role strengthening in the field of ecology is somehow predetermined by the modern configuration of existing system of international relations and the place of Ukraine in it.

At the same time the state role strengthening both inside of the country and in the system of international relations does not means that a burden of transfer to the stable development has to be concentrated on the state without any interaction between state and civil society. In S. Shmidheini opinion, who hold a position of the Head of the Council of entrepreneurs on the questions of stable developmen "it is impossible to realize the stable development conception only by the governmental decisions, because billions of people participate in the manufacture and consumption processes. Governments have to create pre-conditions and conditions of its development" 25 .

While realization of the state ecological function under the conditions of transitional period the role of state administration and regulation will objectively increase.

The state can be called the ecological state if it meets certain criteria, when its functioning is based on certain conditions:

- the Institute for Environmental Rights and Freedoms of Human Rights is materialized in legislation;

- the ecological function of the state and its environmental responsibilities to society and man in accordance with the principle of the rule of law are enshrined in the constitution as a social treaty;

24 Dergachev O. Ukraine in Modern Geopolitical Transformations // Political Thought. - 1998. - № 2. - P.186.

${ }^{25}$ Schmidhaney S. Changing course. Prospects for development and environmental problems: an entrepreneur approach. - M., 1994. 
- environmental law system is developed;

- institutional frameworks have been created to ensure the implementation of the state's ecological function;

- a balanced economic and legal mechanism for environmental protection is formed - there is an independent public control of the society over the implementation of environmental legislation;

- the principle of joint responsibility of the state and society for the future living environment is approved;

- there is a public environmental dialogue;

- the basis of the state environmental policy - the human right to a favorable living environment;

- the ecological and legal culture, which underlies decision-making processes is developed;

- the environmental and legal motivations of the behavior and life of the elite are formed.

\section{CONCLUSIONS}

It can be noted that today we have the reason to speak about the possibility of recognition of Ukraine as an ecological state, which is formed within the framework of the mentioned theoretical and methodological paradigm. In particular, the Constitution of Ukraine enshrines the ecological function of the state, approved the economic and legal mechanism of environmental protection, which implemented the international legal principle "polluter pays". Public organizations have acquired access to participate in determining the state's environmental policy. We have developed advanced environmental legislation that enshrines environmental human rights and freedoms. At their core - the right to environmental safety, guaranteed by Art. 50 of the Constitution of Ukraine. The same model occurs in several other states.

However, in our view, now the right to environmental security must be seen as a manipulation of modern states, driven by their financial capabilities and attempts to find parity between the economic interests of the capital power and the environmental interests of present and future generations. Indeed, the right to environmental safety is based on the obligation of the state to develop, approve and ensure compliance with environmental anthropogenic pollution by entities that do not take into account neither the total effect of the commented pollution, nor the consequences of their long-term impact on human and environment. Hence the need to underpin the State's obligations to civil society for the 
human right to a favorable environment and the principle of the rule of law, which embodies both the recognition of a person of the highest social value and the definition of environmental rights and freedoms, above all, the fundamental human right to favorable environment, which determines the content and orientation of the state.

\section{SUMMARY}

The author once again raises the question of the importance of the formation of an ecological state as a political and legal response of modern civilization to global challenges and environmental threats. The section is dedicated for the first time raises questions about the new role of the state in modern conditions, the state's ability to respond to global challenges using theoretical and legal science and sociology of law as part of his proposed theological and sociological understanding of law. According to the author, to replace the post-industrial state, which is the mechanism maintenance liberal values of society has come a social constitutional state which can maintain democratic values, on the one hand, and find answers to the challenges, on the other hand, provide amplification powerful influence on the developments in society between civil society and state under the constitutional and legal requirements as a social contract. Important here is to find the optimal model of governance on account of author proposed a new vision of functional separation of powers.

\section{REFERENCES}

1. Combating environmental crimes. (Criminal and Criminal Investigation). - K : Sciences. opinion, 1994. - P. 9.

2. Chirkin V.E. The modern state. $-M$ : International. Relations, 2001. - P. 203.

3. Dergachev O. Ukraine in Modern Geopolitical Transformations // Political Thought. - 1998. - № 2. - P. 186.

4. Development strategies of Ukraine: challenges of time and choice / E. Bazovkin, A. Belouk, O. Valevsky, et al. - K : NISD, 1994. - 177 p.

5. History of political and legal studies: Reader for law schools and faculties / Comp. and total ed. Prof. Dr. Dr. East. Sciences G.G. Demidenko. - X : Fact, 1999. - P. 223.

6. Hoya T. Methods of market economy in American and Russian environmental law // Bulletin of the International University. - The Law Series. - Issue 5. - M., 2001. - P. 152. 
7. General theory of state and law. Academic course in 2 volumes. Volume 1. Theory of the State / Ed. MN Marchenko. - M.: "Mirror", 1998. - P. 203-204.

8. Kolbasov O.S. Ecology: politics - law. - M : Science, 1976.

9. Kostytsky V.V. Distribution of power in legal state and social and normative fixing of the idea of freedom and democracy. - Sociology of law. - 2011, № 2, - P. 3-10.

10. Kostytsky V. Ecological function of the state and economic and legal mechanism of environmental protection // Law of Ukraine. - 2004. № 1. - P. 147.

11. Kostytsky V.V. Ecological law as a theological and sociological phenomenon / V. Kostytsky // Ecological law. - 2013. - № 1. - P. 4-12.

12. Kostysky V.V. Ecology of Transition: Law, State, Economy (Economic and Legal Mechanism of Environmental Protection in Ukraine) / V.V. Kostysky; Institute for Legislative Predictions and Legal Expertise. - (Series "Ecological Library"; № 5) (Library of the magazine "Small and Medium Business/-K.: USSB SME Eusmeu, 2003. - 772 p.

13. Kostytsky V.V. Environmental Law of Ukraine: [textbook] 1 book. / Vasyl Kostytsky, - Drohobych: Circle, 2012. - 360 p.

14. Kostytsky V.V. Local stlfgovernment and sustainable use of nature. - K., 1989.

15. Kostytsky V.V. Political Parties in the System "Civil Society and State" // Law of Ukraine.- 1995. - № 12.

16. Kostytsky V.V. Power of the people: seven functional branches of power (Renaissance problems in the theory of law). - Small and Medium Business, 2010. - P. 4-14.

17. Kostytsky Vasyl. State-building processes are components of multiparty development in Ukraine (political and legal analysis). - K., 2002. $-60 \mathrm{p}$.

18. Kostytsky V.V. etc. The interaction of society and nature: sociophilosophical problems. (Lecture notes). - Lviv, 1992. - $32 \mathrm{p}$.

19. Muhamet - Irekle A. On the Function of the Rule of Law in Modern Nature Management. Monograph. - M.: "NIA-Nature", 2002. $272 \mathrm{p}$.

20.Petrov V.V. The concept of interaction between society and nature - the scientific basis of environmental law / Methodological problems of law / Ed. M.N. Marchenko. - M.: Moscow State University Publishing House, 1994. - P. 138. 
21. Political Foundations of Modern State Strategy / Political Studies. Issue 2. - K : Ukrainian Perspective Foundation, 1995 - P. 4.

22. Politology. Textbook / Edited by prof. Kremena V.G., prof. Gorpacha MI - Kharkiv: Unicorn Printing Center, 2001. - 640 p.

23. Problems of the general theory of law and state. Textbook for universities / Under commonly. ed. V.S. Nersesyan. - M.: "Norma", 2001.

24. Shemshuchenko Y.S. Organizational and Legal Issues of Environmental Protection in the USSR. - K.: Sciences. opinion. - 1976 $276 \mathrm{p}$.

25. Sokolov A. Kant and Contemporaneity (concept of legal state in the mirror of comparative law) // Political Reading. - 1995. - № 1. - P. 4.

26. Timoshenko V.I. Legal power: theoretical-historical researches. K.: Naukova Dumka, 1994. - P. 16. Tomenko M. The Ukrainian Perspective: Historical and 27.

27. Spiridonov L.I. State and Law Theory. - M., 1996.

28. Schmidhaney S. Changing course. Prospects for development and environmental problems: an entrepreneur approach. - M., 1994.

29. The history of political and legal doctrines of the XVIIXVIII centuries. / Editorial.: Gratsiansky P.S. and others - M.: Science, 1989. - S. 116-129.

30. The history of political and legal doctrines of the XVIIXVIII centuries. / Editorial.: Gratsiansky P.S. and others - M.: Science, 1989. - P. 198.

31. Valevsky O.L. State policy in Ukraine: methodology of analysis, strategy, mechanisms of implementation. - K : NISD, 2001. P. 121-126.

\section{Information about the author:} Kostytsky V., Doctor of Law (DrSc.), Professor, President of the International Environmental Academy ORCID: 0000-0003-1692-9810 